\title{
Silicified wood from the Permian and Triassic of Antarctica: Tree rings from polar paleolatitudes
}

\author{
P. E. Ryberg and E. L. Taylor \\ Department of Ecology and Evolutionary Biology; Natural History Museum and Biodiversity Research Center, University of Kansas, Lawrence, KS \\ 66045, USA (rybergp@ku.edu; etaylor@ku.edu)
}

\begin{abstract}
The mass extinction at the Permian-Triassic boundary produced a floral turnover in Gondwana in which Paleozoic seed ferns belonging to the Glossopteridales were replaced by corystosperm seed ferns and other seed plant groups in the Mesozoic. Secondary growth (wood production) in both plant groups provides information on plant growth in relation to environment in the form of permineralized tree rings. Techniques utilized to analyze extant wood can be used on fossil specimens to better understand the climate from both of these periods. Late Permian and early Middle Triassic tree rings from the Beardmore Glacier area indicate an environment where extensive plant growth occurred at polar latitudes $\left(\sim 80-85^{\circ} \mathrm{S}\right.$, Permian; $\sim 75^{\circ} \mathrm{S}$, Triassic $)$. A rapid transition to dormancy in both the Permian and Triassic woods suggests a strong influence of the annual light/dark cycle within the Antarctic Circle on ring production. Latewood production in each ring was most likely triggered by the movement of the already low-angled sun below the horizon. The plants which produced the wood have been reconstructed as seasonally deciduous, based on structural and sedimentologic evidence. Although the Late Permian climate has been reconstructed as cold temperate and the Middle Triassic as a greenhouse, these differences are not reflected in tree ring anatomy or wood production in these plant fossils from the central Transantarctic Mountains.

Citation: Ryberg, P. E., and E. L. Taylor (2007), Silicified wood from the Permian and Triassic of Antarctica: tree rings from polar paleolatitudes, in Antarctica: A Keystone in a Changing World - Online Proceedings of the $10^{\text {th }}$ ISAES, edited by A. K. Cooper and C. R. Raymond et al., USGS OpenFile Report 2007-1047, Short Research Paper 080, 5 p.; doi:10.3133/of2007-1047.srp080
\end{abstract}

\section{Introduction}

For much of its history, Antarctica has been covered in vegetation and fossil wood is known from various deposits ranging from the Permian through the Pliocene (e.g., Jefferson, 1982; Francis et al., 1993; Francis and Hill, 1996; Ashworth and Cantrill, 2004; Poole and Cantrill, 2006). In the Permian and Triassic, the continent was located at high latitudes with much of the landmass within the polar circle. Climate reconstructions and geologic evidence confirm that the Early Permian in Antarctica was an icehouse (Isbell et al., 2003; Montañez et al., 2007), followed by warming throughout the period as the Gondwanan glaciation waned (Kiehl and Shields, 2005). By the Middle Triassic, the Earth was in a greenhouse phase (e.g., Kidder and Worsley, 2004; Galfetti et al., 2007) and Antarctica had moved into slightly lower latitudes, although much of it still remained within the polar circle.

In the Late Permian, Gondwana was dominated by the Glossopteris flora, consisting primarily of organs of the glossopterid seed ferns, especially the strap-shaped leaves, Glossopteris, with their distinctive anastomosing venation (Pigg, 1990). Growth rings in Permian Antarctic fossil wood have been analyzed and have provided information on forest growth at high latitudes (e.g., Allan Hills, Francis et al., 1993). The specimens in this study are from the central Transantarctic Mountains (CTM) and represent wood growth from a higher paleolatitude, $\sim 80$ $85^{\circ} \mathrm{S}$ (Permian) and $\sim 75^{\circ} \mathrm{S}$ (Triassic), than previous studies (Scotese, 2002).

At the end of the Permian, a complete floral turnover occurred in Gondwana, and the Glossopteris flora was replaced by different seed plant groups (McLoughlin et al., 1997). By the Middle Triassic, the corystosperm seed ferns were the dominant floral element (McLoughlin et al., 1997; Taylor et al., 2000; Gastaldo et al., 2005). There are few reports of Triassic wood in Antarctica (e.g., Gabites, 1985; Del Fueyo et al., 1995; McLoughlin et al., 1997) and material in this study will provide some of the first data on wood production and tree ring anatomy in the high latitudes of Gondwana during the Triassic.

Both the Permian and Triassic specimens provide information on plant growth at high latitudes before and after an important transition in Earth history. The interactions of these plants with their environments are recorded on an annual basis in their tree rings. Rings form in response to variations in limiting ecological variables, including temperature, water availability, and light, and methods have been developed to correlate ring structure with the environment (Fritts 1976; Schweingruber, 1989).

\section{Materials and methods}

Specimens were collected from Skaar Ridge, McIntyre Promontory, and Fremouw Peak in the Beardmore and Shackleton Glacier area, CTM (Fig. 1), as isolated logs in channel deposits, permineralized peat deposits, and stumps preserved in growth position; all wood is silicified. The Skaar Ridge peat (8949'15.8'S, 16320'18.9'E; Barrett and Elliot, 1973; Taylor et al., 1989) occurs in the upper Buckley Formation and is dated as Late Permian based on palynomorphs and floral content (Farabee et al., 1991). Due to collecting difficulties, only a single specimen (12389) was collected and analyzed from McIntyre Promontory (8422'23'S, $\left.179^{\circ} 45^{\prime} 58^{\prime \prime} \mathrm{E}\right)$, which is also upper Buckley (J. L. Isbell, pers. Comm., 2007). Triassic specimens (both peat and logs) are from Fremouw Peak, upper Fremouw Formation 
$\left(84^{\circ} 17^{\prime} 24.1^{\prime \prime S}, 164^{\circ} 21^{\prime} 24.2^{\prime \prime} \mathrm{E}\right)$ and are dated as early Middle Triassic based on palynomorphs (Farabee et al., 1990).

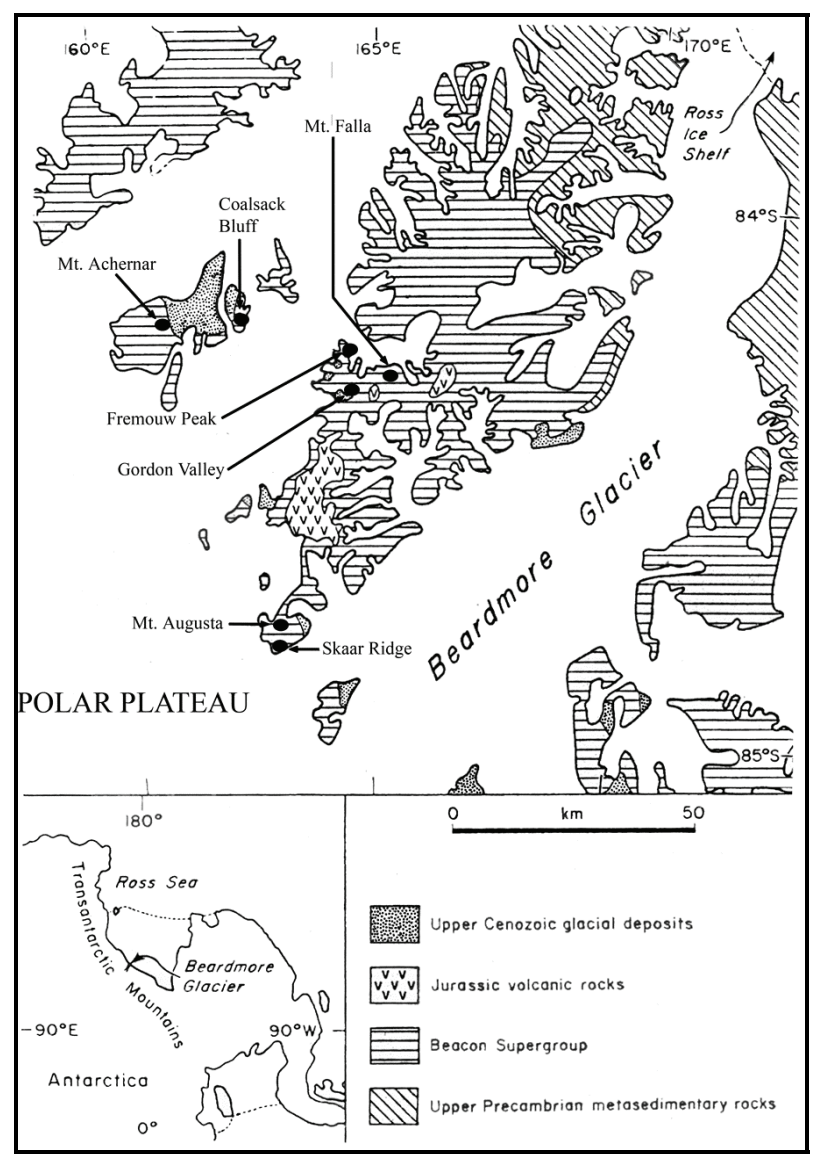

Figure 1. Locality map of the Beardmore Glacier, central Transantarctic Mountains with Skaar Ridge and Fremouw Peak collecting sites labeled.

Specimens were prepared using the acetate peel technique (Galtier and Phillips, 1999) after etching in concentrated hydrofluoric acid. Peels were mounted on slides and measurements made using Wright Cell Imaging Facility's ImageJ (Rasband, 1997-2004) program. All specimens are housed in the University of Kansas, Natural History Museum, Division of Paleobotany under acquisition numbers: Skaar Ridge: 13089-13691, 15485, 15503, 15512, 15514; McIntyre Promontory: 12389; Fremouw Peak: 11208, 11313, 11468, 11475, 11491, $11619,11800,11816,11822,12820,12961,12963-$ 12965, 13007, 13009, 13032, 13655, 13802, 13823.

Modern dendrochronological methods utilize various measurements of wood cells to quantify annual growth response (e.g., Fritts, 1976; Schweingruber, 1989), including ring width, number of cells per ring, and changes in the proportion of radial cell-lumen diameter to cell-wall thickness across each ring. These same measurements can be used to examine plant responses to paleoenvironments (e.g., Creber, 1977; Francis, 1986; Parrish and Spicer, 1988; Francis and Hill, 1996), even when, as in this case, no analogous environment exists today. Data calculations included: mean sensitivity (Fritts, 1976), cumulative sum of tracheid radial cell diameters across a ring (Creber and Chaloner, 1984), and proportion of earlywood (EW) to latewood (LW) (Denne, 1988). Mean sensitivity (m.s.) measures a tree's response to the environment throughout its life by evaluating changes in ring width from year to year. Sensitive trees (m.s. $\geq 0.3$ ) show an annual response to environmental stresses and ring growth is variable from year to year. Complacent trees (m.s. $<0.3)$ do not respond as strongly to annual environmental fluctuations and tend to produce consistent ring widths from year to year. Temperate trees produce both earlywood (spring wood) and latewood (summer wood) in each ring; EW tracheids have a wider cell lumen and thinner cell walls than LW tracheids. Earlywood is produced during extensional growth of the tree and LW after apical elongation stops (Larson, 1960, 1962); this developmental change is regulated by plant hormones and related to day length and water availability. EW-LW boundary was defined using the classic plant anatomydendrology method of Mork (1928), as interpreted by Denne (1988), which defines LW as the point of $2 a \geq b$, where $a=$ wall thickness of two adjacent cells, and $b=$ lumen diameter. For comparison, we also calculated EWLW boundary using the CSDM method of Creber and Chaloner (1984), which depends upon the cumulative sum of radial cell (tracheid) diameters and their deviation from the mean across a ring.

Table 1. Fossil tree ring measurements. CSDM= cumulative sum of deviation from the mean (see text).

\begin{tabular}{|c|c|c|}
\hline & Permian & Triassic \\
\hline No. of specimens & 8 & 21 \\
\hline Mean no. rings & 30 & 62 \\
\hline Mean width (mm) & 2.3 & 1.69 \\
\hline Mean no. cells/ring & 36 & 45 \\
\hline Mean sensitivity & 0.34 & 0.31 \\
\hline Mork (1928) latewood & $1-5$ cells & $1-6$ cells \\
\hline CSDM latewood & $16-70$ cells & $14-104$ cells \\
\hline
\end{tabular}

\section{Results}

\section{Late Permian rings}

Rings in the Permian glossopterid wood ranged from $0.20-9.9 \mathrm{~mm}$ wide (mean: $2.3 \mathrm{~mm}$ ) (Table 1), with up to 115 rings, indicating that mature wood was used in measurements. The trees are classified as sensitive (m.s. $=$ $0.30-0.37$; mean $=0.34)$. Up to 234 cells were produced in a single ring (average $=64$ cells/ring) (Fig. 2). Using Mork's (1928) method, the Permian woods contain only 1-5 cells of LW per ring (Figs. 2, 3). The CSDM method results in approximately 16-70 cells of latewood (Fig. 4). 


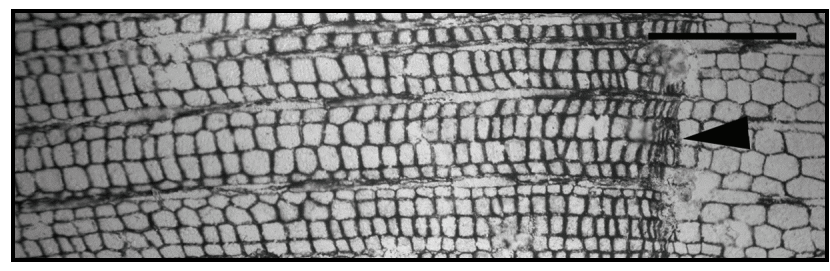

Figure 2. Permian tree ring showing large number of earlywood cells (left) and narrow band of latewood cells (arrow). Center of stem is toward the left. Bar scale $=0.5$ $\mathrm{mm}$ (15485 G top \#2).

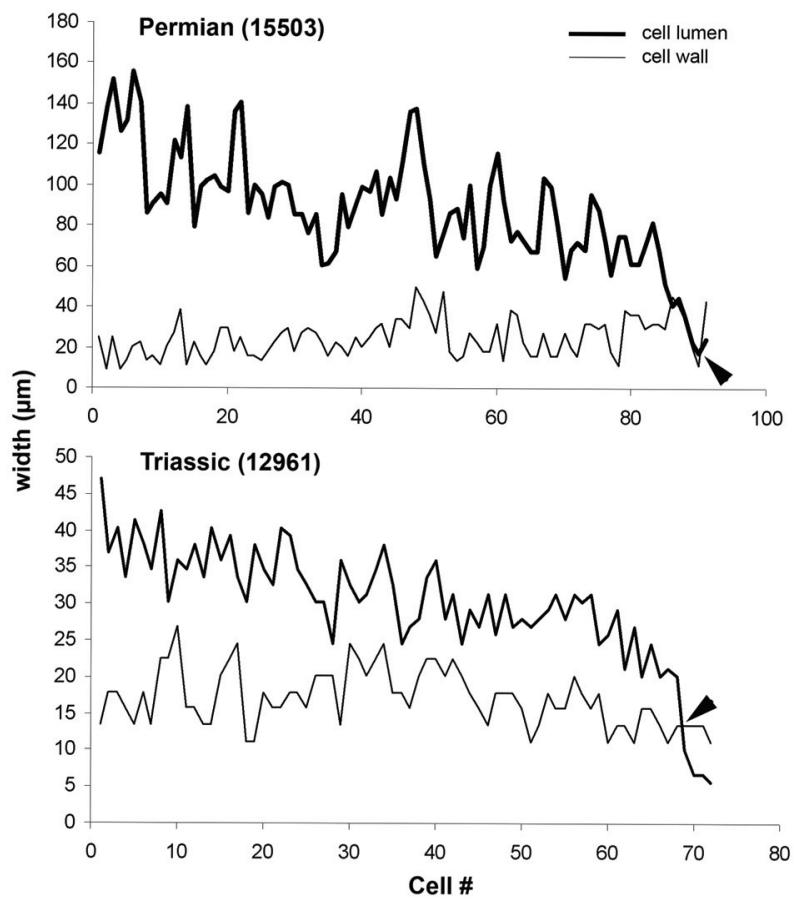

Figure 3. Earlywood/latewood boundary as defined by Mork (1928). Boundary occurs where the thin line crosses over the thick line indicating only a few cells of latewood (arrows).

\section{Middle Triassic rings}

Rings of Triassic corystosperm wood measured 0.08$6.83 \mathrm{~mm}$ in width, with a maximum of 136 rings (Table $1)$. The wood is classified as sensitive (m.s. $=0.14-0.45$; mean $=0.31)$. Individual rings contained up to 110 cells (average $=45$ ). Latewood consists of only 1-6 cells according to Mork's (1928) definition (Fig. 3), but 14104 cells, using the CSDM method (Fig. 4).

\section{Discussion}

The presence of such extensive wood production in the Late Permian of Antarctica confirms that mature forests were able to thrive in the presumably cold climate (Kiehl and Shields, 2005) at that time (see also Francis et al., 1993). While the Triassic specimens had more rings overall, the Permian rings were slightly wider (Table 1), but this difference may be due to small sample sizes and the variable age (in years) of the wood. The mean sensitivities of both Permian and Triassic wood samples

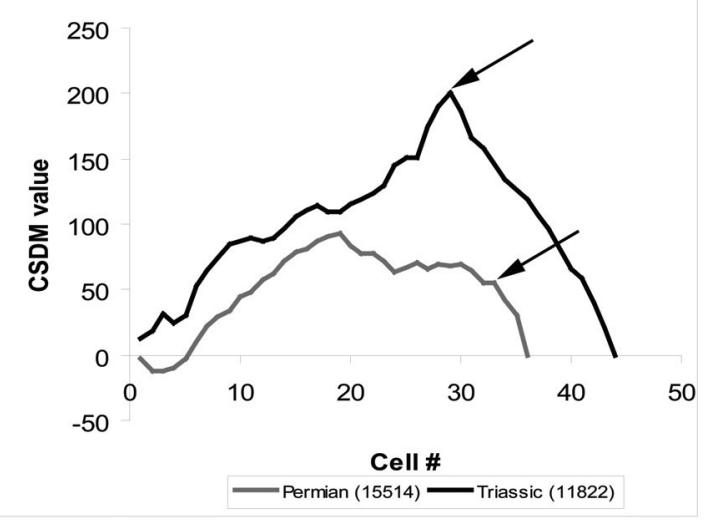

Figure 4. CSDM curves based on Permian and Triassic wood, showing 5-15 cells of latewood. Arrows = EW/LW boundary.

(Table 1) classify both as sensitive. This indicates that although there was extensive growth in the wood, production of wood varied from year to year as the plants responded to annual changes in the environment.

The two methods used to determine the EW/LW boundary produced conflicting results in both the Permian and Triassic woods. The CSDM curve, which has previously been used in several analyses of fossil wood (e.g., Creber and Chaloner, 1984; Francis 1986), resulted in nearly half of the wood produced in a season being designated as latewood (e.g., Fig. 4). In modern plants, the EW-LW transition begins when young shoots on the tree cease elongation growth; in temperate zones, this usually occurs in late spring-early summer. Using Mork's (1928) method, 1-5 cells of LW are present per ring in both the Permian and Triassic wood. Comparing these results with the structure of the wood (Fig. 2), it is apparent that the classical method of defining the EW-LW boundary provides a more accurate characterization of these high paleolatitude woods. The tree rings clearly show that tree growth did not slow during the growing season, based on the continuous production of earlywood, but continued unabated until the very end of the season, when a few rows of latewood were produced.

There has been much debate over whether evergreen or deciduous trees have higher survival rates at polar latitudes (e.g., Spicer and Chapman, 1990; Royer et al., 2003; Royer et al., 2005). There are several lines of evidence for deciduousness in these Antarctic fossil plants. Glossopteris leaves occur in dense leaf mats at the Skaar Ridge locality and have been found in varved deposits elsewhere in Gondwana (e.g., Plumstead, 1958; Gunn and Walcott, 1962). In the Triassic corystosperms, a layer of periderm tissue forms below the attachment point of the leaves (Meyer-Berthaud et al., 1993), indicating that there was a regular physiologic mechanism in these plants to drop their leaves. 
The structure of the Antarctic tree rings, with extensive EW and very little LW, is completely unlike those seen in temperate woods today, but is similar to other fossil wood described from very high paleolatitudes (e.g., Francis, 1986; Spicer and Parrish, 1986), suggesting that tree growth in Antarctica at this time was influenced by a parameter that does not limit tree growth today. The limiting factors in high-latitude tree growth today are water availability and temperature. The structure of the fossil tree rings, as well as other evidence (Taylor et al., 2000), indicates that these were not the limiting factors in the Permian and Triassic forests of Antarctica. The presence of forests at high latitudes during warm periods of Earth history provides evidence that tree growth can occur at extremely high latitudes (Jefferson, 1982; Parrish and Spicer 1988; Read and Francis, 1992; Poole and Cantrill, 2006). At polar latitudes, darkness envelops the landscape for much of the year, preventing photosynthesis from occurring. The structure of the rings indicates that light availability is the parameter which limited growth and controlled tree ring formation at these high latitudes. The extremely low numbers of LW cells and the rapid change from EW to LW in both Permian and Triassic specimens indicate that there was a rapid transition to dormancy in these trees as the low-angled sun fell below the horizon, causing leaf abscission, followed by winter dormancy.

\section{Summary}

Tree ring analysis of Permian and Triassic silicified wood from south polar paleolatitudes provides data on plant responses to the environment during a time of global climate transition from icehouse to greenhouse. Extensive growth, as shown by numerous, large annual tree rings, is observed in both periods, in an environment for which there is no modern analog. Ring structure confirms that temperatures and water availability were adequate for growth throughout the growing season, suggesting that tree growth was mediated by a parameter not observed in modern tree ring formation. Ring structure, especially the proportion of earlywood to latewood in each ring, indicates that light availability was the most likely factor controlling tree ring structure in Late Permian and Middle Triassic forests in Antarctica. The extreme seasonal light and dark cycles in this polar environment were no doubt also a major factor contributing to the deciduous nature of both Permian glossopterid and Triassic corystosperm seed ferns in these forests.

\section{References}

Ashworth, A. C., and D. J. Cantrill (2004), Neogene vegetation of the Meyer Desert Formation (Sirius Group) Transantarctic Mountains, Antarctica, Palaeogeogr. Palaeoclimatol., Palaeoecol., 213, 65-82.

Barrett, P. J., and D. J. Elliot (1973), Reconnaissance geologic map of the Buckley Island Quadrangle, Transantarctic Mountains, Antarctica, Antarctic Geologic Map (U. S. Geological Survey) A-3.

Creber, G. T. (1977), Tree rings: a natural data-storage system, Biol. Rev., 52, 349-383.
Creber, G. T., and W. G. Chaloner (1984), Influence of environmental factors on the wood structure of living and fossil trees, Bot. Rev., 50, 357-448.

Del Fueyo, G. M., E. L. Taylor, T. N. Taylor, and N. R. Cúneo (1995), Triassic wood from the Gordon Valley, central Transantarctic Mountains, Antarctica, IAWA Journal, 16, 111-126.

Denne, M. P. (1988), Definition of latewood according to Mork (1928), IAWA Bull., 10, 59-62.

Farabee, M. J., E. L. Taylor, and T. N. Taylor (1990), Correlation of Permian and Triassic palynomorph assemblages from the central Transantarctic Mountains, Rev. Palaeobot. Palynol., 65, 257-265.

Farabee, M. J., E. L. Taylor, and T. N. Taylor (1991), Late Permian palynomorphs from the Buckley Formation in the central Transantarctic Mountains, Rev. Palaeobot. Palynol., 69, 353-368.

Francis, J. E. (1986), Growth rings in Cretaceous and Tertiary wood from Antarctica and their palaeoclimatic implications, Palaeontology, 48, 285-307.

Francis, J. E., and R. S. Hill (1996), Fossil plants from the Pliocene Sirius Group, Transantarctic Mountains: evidence for climate from growth rings and fossil leaves. Palaios, 11, 389-396.

Francis, J. E., K. J. Woolfe, M. J. Arnot, and P. J. Barrett (1993), Permian forests of Allan Hills, Antarctica: the palaeoclimate of Gondwanan high latitudes, Spec. Pap. Palaeontol., 49, 75-83.

Fritts, H. C. (1976), Tree Rings and Climate, Academic Press, New York.

Gabites, H. I. (1985), Triassic paleoecology of the Lashly Formation, Transantarctic Mountains, Antarctica. Unpublished M.Sc. thesis, Victoria University of Wellington, New Zealand.

Galfetti, T., H. Bucher, A. Brayard, P. A. Hochuli, H. Weissert, G. Kuang, V. Atudorei, J. Guex (2007), Late Early Triassic climate change: Insights from carbonate carbon isotopes, sedimentary evolution and ammonoid paleobiogeography, Palaeogeogr. Palaeoclimatol., Palaeoecol., 243, 394-411.

Galtier, J. M., and T. L. Phillips (1999), The acetate peel technique, in Fossil Plants and Spores: Modern Techniques, edited by T. P. Jones, and N. P. Rowe, pp. 67-70, Geol. Soc. Lond., UK.

Gastaldo, R. A., R. Adendorff, M. Bamford, C. C. Labandeira, J. Neveling, and H. Sims (2005), Taphonomic trends of macrofloral assemblages across the Permian-Triassic boundary, Karoo Basin, South Africa, Palaios, 20, 479-497.

Gunn, B. M., and R. I. Walcott (1962), The geology of the Mt. Markham region, Ross dependency, Antarctica, N. Z. J. Geol. Geophys., 5, 407426.

Isbell, J. L., P. A. Lenaker, R. A. Askin, M. F. Miller, and L. E. Babcock (2003), Reevaluation of the timing and extent of late Paleozoic glaciation in Gondwana: role of the Transantarctic Mountains, Geology, 31, 977-980.

Jefferson, T. H. (1982), Fossil forests form the Lower Cretaceous of Alexander Island, Antarctica, Palaeontology, 25, 681-708.

Kidder, D. L., and T. R. Worsley (2004), Causes and consequences of extreme Permo-Triassic warming to globally equable climate and relation to the Permo-Triassic extinction and recovery, Palaeogeogr. Palaeoclimatol. Palaeoecol., 203, 207-237.

Kiehl, J. T., and C. A. Shields (2005), Climate simulation of the latest Permian: implications for mass extinction, Geology, 33, 757-760.

Larson, P. R. (1960), A physiological consideration of the springwood summerwood transition in red pine, Forest Sci., 6, 110-122.

Larson, P. R. (1962), The indirect effect of photoperiod on tracheid diameter in Pinus resinosa, Am. J. Bot., 49, 132-137.

McLoughlin, S., S. Lindstrom, and A. N. Drinnan (1997), Gondwanan floristic and sedimentological trends during the Permian-Triassic transition: new evidence from the Amery Group, northern Prince Charles Mountains, East Antarctica, Ant. Sci., 9, 281-298.

Meyer-Berthaud, B., T. N. Taylor, and E. L. Taylor (1993), Petrified stems bearing Dicroidium leaves from the Triassic of Antarctica, Palaeontology, 36, 337-356.

Montañez, I. P., N. J. Tabor, D. Niemeier, W. A. DiMichele, T. D. Frank, C. R. Fielding, J. L. Isbell, L. P. Birgenheier, and M. C. Rygel (2007), CO2-forced climate and vegetation instability during Late Paleozoic deglaciation, Science, 315, 87-91. 
Mork, E. (1928), Die Qualität des Fichtenholzes unter besonderer Rücksichtnahme auf Schleif- und Papierholz, Der Papier-Fabrikant, 26, 741-747.

Parrish, J. T., and R. A. Spicer (1988), Middle Cretaceous wood from the Nanushuk Group, central North Slope, Alaska, Palaeontology, 31, 19-34.

Pigg, K. B. (1990), Anatomically preserved Glossopteris foliage from the central Transantarctic Mountains, Rev. Palaeobot. Palynol., 66, 105-127.

Plumstead, E. P. (1958), The habit of growth of Glossopteridae, Trans. Geol. Soc. S. Africa, 61, 81-96.

Poole, I., and D. J. Cantrill (2006), Cretaceous and Cenozoic vegetation of Antarctica integrating the fossil wood record, in CretaceousTertiary High-Latitude Palaeoenvironments, James Ross Basin, Antarctica, edited by J. E. Francis, D. Pirrie, and J. A. Crame, pp. 6381, Geol. Soc. Lond. Spec. Pub., London, UK.

Rasband, W. S. (1997-2004), ImageJ. National Institutes of Health, Bethesda, Maryland, USA, http://rsb.info.nih.gov/ij/.

Read, J., and J. Francis (1992), Responses of some Southern Hemisphere tree species to a prolonged dark period an their implications for highlatitude Cretaceous and Tertiary floras, Palaeogeogr. Palaeoclimatol. Palaeoecol., 99, 271-290.

Royer, D. L., C. P. Osborne, and D. J. Beerling (2003), Carbon loss by deciduous trees in a $\mathrm{CO} 2$-rich ancient polar environment, Nature, 424 , 60-62.

Royer, D. L., C. P. Osborne, and D. J. Beerling (2005), Contrasting seasonal patterns of carbon gain in evergreen and deciduous trees in ancient polar forests, Paleobiology, 31, 141-150.

Schweingruber, F. H. (1989), Tree Rings: Basics and applications of dendrochronology, Kluwer, Dordrecht. Scotese, C. R. (2002), http://www.scotese.com, (PALEOMAP website).

Spicer, R. A., and J. L. Chapman (1990), Climate change and the evolution of high-latitude terrestrial vegetation and floras, Trends Ecol. Evol., 5, 279-284.

Spicer, R. A., and J. T. Parrish (1986), Paleobotanical evidence for cool North Polar climates in middle Cretaceous (Albian-Cenomanian) time, Geology, 14, 703-706.

Taylor, E. L., T. N. Taylor, and J. W. Collinson (1989), Depositional setting and paleobotany of Permian and Triassic permineralized peat from the central Transantarctic Mountains, Antarctica, Internat. J. Coal Geol., 12, 657-679.

Taylor, E. L., T. N. Taylor, and N. R. Cúneo (2000), Permian and Triassic high latitude paleoclimates: evidence from fossil biotas, in Warm Climates in Earth History, edited by B. T. Huber, K. G. MacLeod, and S. L. Wing, pp. 321-350, Cambr. Univ. Press, Cambridge, UK. 